\title{
The Effect of Second Language Reading Strategy Instruction on Young Iranian EFL Learners' Reading Comprehension
}

\section{Jalil Fathi}

Asst. Prof. in TEFL, University of Kurdistan, Iran, jfathi13@yahoo.com

\section{Maryam Afzali}

MA Student in TEFL, Islamic Azad University, Iran, afzalighazale@yahoo.com

$$
\mid
$$

The objective of the current paper was set to examine the effect of second language reading strategy instruction on young Iranian English as a Foreign Language (EFL) learners' reading comprehension. To accomplish this objective, a sample of 48 Iranian EFL learners, aged 11-13, were selected and randomly assigned to an experimental group $(\mathrm{N}=25)$ and a control group $(\mathrm{N}=23)$. Employing a quasi-experimental design, the study employed an experimental group that underwent a 12-week reading strategy instruction and a control group that were taught with regular method with no strategy instruction but they were measured in terms of reading comprehension before and after the strategy instruction. The reading component of Cambridge Preliminary English Test (CPET) was given to assess the reading comprehension performance of the participants as pre-test and post-test of the study. The collected data were analyzed through conducting paired samples t-test and one-way ANCOVA. The findings of the study revealed that the learners in the experimental group outperformed those of control group with regard to reading comprehension after receiving the strategy instruction intervention. Pedagogical implications on reading strategy instruction were also discussed.

Keywords: reading strategy instruction, reading comprehension, EFL, strategy-based instruction, quasi-experimental design

\section{INTRODUCTION}

Reading is a process which is conceptualized as the decoding of printed symbols into phonological forms so as to understand the meaning of the printed texts (Koda, 2007; Ziegler \& Goswami, 2006). Nevertheless, this process of comprehension of meaning is not one-dimensional but the reader should possess adequate vocabulary knowledge and know how to compose the sentences and how to process the information extracted from the passage with prior knowledge (Koda, 2007). Therefore, in addition to linguistic 
knowledge, readers should employ their world knowledge, experiences, and strategies to comprehend a text (Bouvet \& Close, 2006). Furthermore, reading process also requires that readers employ a number of particular modes of operations known as "reading strategies" so as to comprehend a text (Kern, 1989, p. 135). It is argued that learners employ more reading strategies when encountered with more difficult texts (Anderson, 1991; Bimmel, van den Bergh, \& Oostdam, 2001). Good readers are also claimed to employ a set of reading strategies to understand a written text (Duke \& Pearson, 2002; Sheorey \& Mokhtari, 2001; Taylor, Steven \& Asher, 2006; Zhang \& Wu, 2009). Such readers are active readers, have specific and obvious goals in mind, are conscious of a set of reading strategies and employ them to regulate and improve their own understanding (Erler \& Finkbeiner, 2007; Zhang \& Wu, 2009).

Reading strategies are subsumed under language learning strategies which are claimed to positively affect and facilitate language learning process (Oxford et al., 2004). In other words, the burgeoning body of literature on language learning strategies suggests that strategy teaching motivates L2 learners to use strategies more effectively (Chamot, 2005), and that there is a significant positive relationship between the successful strategy use and successful L2 learning (Oxford et al., 2004). Considered as a category of language learning strategy, reading strategies are defined as "a plan of mental actions to achieve a reading goal" (Bimmel et al., 2001, p. 510). They are also viewed as "the mental operations or comprehension processes that readers select and apply in order to make sense of what they read' (Abbott, 2006, p. 637). Reading strategies contribute positively to learning process if they are used effectively in various contexts (Grabe, 2009). As a result, although there might be overlap across different categories of strategies (Phakiti, 2003), metacognitive strategies may be considered more effective as they influence the effective use of reading strategies among readers whose metacognitive reading strategy awareness has been raised (Cohen, 2007).

Given the significance of second language (L2) reading strategies in successful L2 reading, an accumulated body of empirical studies has acknowledged the influential role of direct teaching of L2 reading strategies in enhancing L2 reading skills and competencies (Akkakoson, 2013). Williams and Burden (1997) stated that L2 teachers should not confine themselves to the delivery of knowledge but they should help students to become equipped with the knowledge, skills, competencies, and strategies required to become more autonomous readers. Explicit instruction of reading strategies also aid L2 learners in improving their performance on exams involving comprehension and recall of what is being read (Brown \& Palincsar, 1989; Carrell, Pharis, \& Liberto, 1989). Previous studies have also indicated that teaching of reading strategies not only improves students' reading comprehension proficiency but also raises their consciousness of the strategies of L2 reading comprehension (e.g., Davis, 2010; Wright \& Brown, 2006).

As far as L2 strategy instruction models are concerned, several strategies have been proposed by strategy researchers and practitioners (Chamot \& O'Malley, 1996; Cohen \&Weaver, 2005; Oxford, 2011). One of the famous strategy-based instruction models is Cognitive Academic Language Learning Approach (CALLA) which was constructed 
and used in the United States in order to compensate for the learning inadequacies of L2 learners (Chamot \& O’Malley, 1996). The findings of other empirical studies employing CALLA indicated that this model can be utilized at different educational levels and contexts in foreign language learning (Chamot, Barnhardt, El-Dinary \& Robbins, 1999). CALLA constitutes three key elements including content topics, academic language development, and direct teaching of learning strategies (Chamot \& O'Malley, 1994). The content is selected among the topics which are consistent with the levels of students and their field of study. Given the significant topics in students' fields of study, it is recommended that the interest and motivation of students be also taken into account while selecting topics (Chamot \& O'Malley, 1994). Content aids L2 learners in increasing their knowledge structure in different topics and improves their motivation (Chamot \& O'Malley, 1994). One defining characteristic of CALLA is that explicit strategy instruction is integrated into regular language instruction. The main objective of explicit strategy instruction is to provide L2 students with a set of strategies that can be employed depending on specific learning tasks (Chamot \& O'Malley, 1994). As far as L2 learning is concerned, it is necessary that learners be trained explicitly to gain more awareness and proficiency with a wide repertoire of strategies which are necessary for more effective language learning (Cohen, 2007). Therefore, explicit strategy instruction within CALLA is carried out by first making decisions about content goals and learning tasks; and then appropriate strategies harmonious with the content and tasks should be identified (Chamot \& O'Malley, 1994). This model has also been employed by numerous researchers investigating the impact of the strategy instruction on reading ability and reading strategy use. The findings of many of these studies revealed that strategy instruction programs using CALLA has positively influenced reading comprehension and reading strategy use (Çubukçu, 2008; Plonsky, 2011; Takallou, 2011).

Although a growing body of empirical studies have employed CALLA as a framework for L2 reading strategy instruction, there is a scarcity of empirical studies exploring the effectiveness of this model for reading strategy instruction among young learners in EFL contexts (Manoli, Papadopoulou, \& Metallidou, 2016). The importance of conducting strategy-instruction studies involving younger L2 learners has been called for by numerous researchers (e.g., Chamot, 2005; Macaro \& Erler, 2008; Manoli, Papadopoulou, \& Metallidou, 2016) since the vast majority of studies have recruited older students. Additionally, concerning the Iranian EFL context, it appears that most Iranian L2 practitioner employ rather traditional and teacher-oriented reading instruction methods and they pay little attention to explicit teaching of strategies in their L2 courses (Fathi \& Hamidizadeh, 2019). For these reasons, the current study was set to explore the impact of L2 reading strategy instruction, set within CALLA model, on young Iranian EFL learners' reading comprehension.

\section{REVIEW OF LITERATURE}

Given the theoretical and empirical evidence supporting the explicit instruction of reading strategies in $\mathrm{L} 2$ research, numerous researchers have investigated the impact of teaching reading strategies on reading comprehension ability and use of reading 
strategies in EFL contexts. For example, Zhang (2008) explored the effect of a twomonth strategy-based reading instruction program on the 99 Chinese EFL learners' comprehension of reading and their tendency to be involved in strategy-based reading instruction in group classroom activities. The reading strategy instruction program was based on constructivist framework which focused on the learners' academic reading comprehension. The results of the study demonstrated that the strategy-based reading instruction based on participatory activities enhanced EFL learners' employment of reading strategies and their reading comprehension performance. In another study conducted by Shang (2010), the employment of three reading strategies including cognitive, metacognitive, and compensation strategies in addition to their perceived effect on the learners' self-efficacy and the effect of reading strategy use and perceived self-efficacy on reading comprehension was investigated. The participants of the study were a sample of Taiwanese EFL learners. The findings of this study revealed that metacognitive strategy was the most frequently employed strategy, followed by compensation strategy, and then cognitive strategy. Furthermore, a significant positive correlation was found between the use of reading strategies and perceptions of selfefficacy. Nevertheless, no relationship was found between reading strategies and reading achievement.

Similarly, Akkakoson (2013) examined the relationship among strategic reading instruction, the process of learning second language-based reading strategies and English reading achievement for Thai university students of science and technology. For the purpose of the study, the experimental group $(\mathrm{N}=82)$ were taught according to a strategy-based instruction program for a period of 16 weeks, whereas the control group $(\mathrm{N}=82)$ were taught based on a traditional, teacher-centered approach. The results of the study showed that the experimental group outperformed the control group after the experimental investigation. Also, Dabarera, Renandya, and Zhang (2014) explored the effect of teaching metacognitive strategies on reading comprehension among a sample of 67 ESL learners in Singapore. Apart from the quantitative data collection techniques, semi-structured interviews were conducted to collect qualitative data on learner experiences with metacognitive strategy instruction. The experimental treatment involved the explicit instruction of metacognitive reading strategies through the Reciprocal Teaching approach. The results of the study revealed that there is a relationship between metacognitive awareness-raising and reading comprehension enhancement. Furthermore, metacognitive strategy instruction proved to be influential in increasing metacognitive awareness, and was moderately correlated with reading comprehension gains.

Having carried out a study in Iranian context, Aghaie and Zhang (2012) examined the effect of explicit reading strategy instruction on EFL students' reading performance. Using a quasi-experimental design involving a control group and an experimental group, the researchers investigated the effects of a four-month period of explicit instruction of cognitive and metacognitive reading strategies on reading performance and strategy use. The findings of the study revealed that explicit strategy-based instruction improved both reading comprehension and reading strategy use. Moreover, the results revealed that strategy instruction enhanced autonomous reading behaviors of the participants. 
Likewise, Mehrpour, Sadighi, and Bagheri (2012) carried out a study to investigate the effect of reading comprehension strategy instruction for a group of Iranian EFL preuniversity students in order to extend the repertoire of strategies they employed and to improve their reading comprehension ability. In so doing, the researchers selected 90 female pre-university students majoring in Natural Sciences according to a convenient sampling procedure. Then the experimental group $(\mathrm{N}=53)$ were taught how to use reading comprehension strategies while reading some English texts during a period of 15 sessions, whereas the control group $(\mathrm{N}=37)$ were taught traditionally, with no strategy instruction. The findings of the study revealed that while reading strategy instruction seemed to have raised students' awareness of reading strategies and encouraged strategy use, some strategies were less likely to be learned and used by the learners. Additionally, it was found that the reading strategy instruction failed to improve the students' reading performance significantly.

More recently, Manoli, Papadopoulou, and Metallidou (2016) examined the immediate and delayed impacts of a strategy instruction program using multiple strategies on EFL students' reading comprehension. The participants of their study constituted 99, 11-12 year-old, Greek-speaking EFL learners. Employing a quasi-experimental design, the researchers investigated the effect of a three-month strategy instruction intervention according to the Direct Explanation framework on the reading performance of the participants of the experimental group. The findings of the study revealed that the students in the experimental group outperformed those of control group both on the immediate and delayed posttests. Overall, the findings of the study supported the usefulness and efficacy of explicit multiple-strategy instruction for young learners in EFL contexts.

\section{METHOD}

This study employed a quantitative research method. Since two intact classes were used as the experimental and control groups in this study, the design of this study is considered as a quasi-experimental design that is a design in which the participants are not randomly selected but other strategies (i.e., pre-test and control group) may be used to exert some control over extraneous variables (Ary, Jacobs, Irvine, \& Walker, 2018).

\section{Participants}

To accomplish the objectives of the current paper, two intact classes of young Iranian EFL learners $(n=48)$ were selected using convenience sampling from a language center in Tehran, Iran. The participants ranged from 11 to 13 years old and were all female. The two intact groups were randomly assigned into an experimental group $(\mathrm{N}=25)$ and a control group $(\mathrm{N}=23)$. To guarantee the homogeneity of the experimental and the control groups in terms of general English proficiency level "Oxford Placement Test" (OPT) (Allan, 2004) was given to the students of both groups. The results obtained from OPT indicated that the learner was of lower intermediate level of language proficiency (B1). The two classes were taught by the same teacher who employed the same coursebook and materials. The experimental intervention (i.e., reading strategy instruction) lasted for a period of 12 weeks. 


\section{Instruments}

\section{English proficiency test}

Oxford Placement Test (OPT) (Allan, 2004) was given to both groups in order to determine the homogeneity of the participants in terms of their general English proficiency. OPT is claimed to be the appropriate test to identify the English proficiency level of any number of learners at all levels (Allan, 2004). OPT consists of a 6 rating scale; students whose score fall between 0-17 are labeled as basic (A1), and students whose scores fall between 18-29 are viewed as elementary students (A2). Those whose scores lie between 30 and 39 are in the lower intermediate group (B1). Those with the scores of 40-47, are considered as upper intermediate (B2) and the students with the scores 48-54, and 54-60 are labeled as advanced (C1) and very sophisticated (C2) levels respectively. The reliability index of OPT as estimated by Cronbach's alpha was reported to be 0.82 in this study.

\section{Reading comprehension test}

In the current study, the participants' performance on reading comprehension was measured by two different versions of the reading component of the Cambridge Preliminary English Test 4 (CPET), one prior to and one after the reading strategy instruction, to investigate whether the strategy-based instruction significantly influenced the participants' reading comprehension performance. CPET is at Level B1 of the Common European Framework of Reference for Languages (CEFR). The reading component of CPET seeks to assess a set of skills and competencies required in reading comprehension at the intermediate level. The two versions of the test employed in this study consisted of five parts. In Part 1 (Questions 1-5), the testees were presented with a list of signs or texts and they were required to choose the best description according to the text. In Part 2 (Questions 6-10), there were a number of people in the left and short descriptions in the right. The students were required to choose from one of the descriptions that best matched each person. The third part of the test (Questions 11-20) included a set of sentences according to a reading passage. The testees were required to judge whether the sentence was true or not. In Part 4 (Questions 21-25), there were five multiple-choice items with one reading passage and the testees were required to choose the most appropriate answer among four written options. In the last part (Questions 2635 ), there was a cloze test with ten multiple-choice items to measure the learners' vocabulary and grammatical knowledge. The reliability coefficient of CPET as measured by Cronbach's alpha for the pre- and posttests was 0.81 and 0.84 , respectively.

\section{Procedure}

Before beginning the experimental treatment, OPT was administered to the participants of the study to ensure their homogeneity. Then to accomplish the objective of the study, a 12-week strategy instruction program focusing on reading strategy instruction was integrated into the regular reading instruction of the experimental group. During the first session of the experimental treatment, the instructor discussed reading strategy instruction to the participants very briefly and provided them with an overview of the 
procedure of the whole intervention period according to the adopted strategy instruction model in the study.

The strategy instruction intervention for the present study was based on Cognitive Academic Language Learning Approach (CALLA) (Chamot \& O`Malley, 1994) framework developed by Chamot et al. (1999) which constitutes five key stages including preparation, presentation, practice, evaluation, and expansion. In this framework, the instruction gradually moves from a highly explicit instruction to a more implicit teaching of using strategies to learning tasks so that the language learners can begin to accept more responsibility in selecting and implementing appropriate learning strategies. This cycle reiterates when new strategies are added to students' strategic repertoires. The detailed description of each stage accompanied by its relevant activities for the reading strategy-based instruction is presented in Table 1.

Table 1

Description of Reading Strategy-Based Instruction

\begin{tabular}{|c|c|c|c|}
\hline & Stage & Purpose & Example activities \\
\hline 1 & Preparation & $\begin{array}{l}\text { to aid students in identifying the strategies they have } \\
\text { already employed in different reading tasks and to raise } \\
\text { their consciousness of the potential effects of employing } \\
\text { strategies and their successful learning. } \\
\text { By activating learners' background knowledge about their } \\
\text { present employment of reading strategies, the teacher is } \\
\text { able to identify the needs of the learners for teaching } \\
\text { reading strategies. }\end{array}$ & $\begin{array}{l}\text { Group discussions on strategies employed recently for reading } \\
\text { tasks, collective or individual talks about particular strategies } \\
\text { employed for particular treading tasks, stimulated recall } \\
\text { procedures in which learners verbalize their thinking when they } \\
\text { carry out a specific task, self-report scales or inventories on } \\
\text { employed reading strategies. }\end{array}$ \\
\hline 2 & Presentation & $\begin{array}{l}\text { Teacher explains and models different reading strategies } \\
\text { and provides the students with details about the features, } \\
\text { effectiveness, and different uses of various strategies. }\end{array}$ & $\begin{array}{l}\text { The teacher himself thinks aloud while reading a text shown on } \\
\text { the overhead projector. } \\
\text { While reading, he showed the use of strategies like predicting the } \\
\text { content according to the title, using pictures to activate } \\
\text { schematic knowledge of the headings, paying particular attention } \\
\text { to topics and bold-faced or italicized text, self-assessing } \\
\text { comprehension and planning on how unknown words, grammar, } \\
\text { or information can be addressed, assessing how successful the } \\
\text { individual has been in text comprehension. } \\
\text { Afterwards, the teacher can request that students reflect on the } \\
\text { strategies they observed, and the teacher can further explain the } \\
\text { strategies with providing the technical name for each strategy, } \\
\text { and discuss how a particular strategy can be employed more } \\
\text { productively. This acts as a kind of modeling for students by } \\
\text { which they could imagine themselves carrying out a particular } \\
\text { reading task successfully. }\end{array}$ \\
\hline 3 & Practice & $\begin{array}{l}\text { Students are provided with the opportunity of practicing } \\
\text { the reading strategy with authentic reading tasks. } \\
\text { The practice may occur repeatedly when the learners are } \\
\text { engaged in doing group work with peers. }\end{array}$ & $\begin{array}{l}\text { A number of learners may read a story, talk about unknown } \\
\text { words in the text and try to guess the meanings from the context, } \\
\text { and take turns summarizing the key points of the story. Strategy } \\
\text { inventories can be practiced with different reading tasks, and may } \\
\text { include any repertoire of language modalities. }\end{array}$ \\
\hline 4 & Evaluation & $\begin{array}{l}\text { Students are provided with chances to self-assess their } \\
\text { success in employing reading strategies, thereby increasing } \\
\text { their metacognitive awareness of their own improvement in } \\
\text { L2 reading. } \\
\text { Students are given activities which enhance their self- } \\
\text { assessment competence }\end{array}$ & $\begin{array}{l}\text { Self-evaluative discussions after practicing new strategies, } \\
\text { keeping journals in which learners keep the outcomes of their } \\
\text { own using of reading strategies, preparing an inventory of } \\
\text { strategies employed, and using open-ended self-report scales in } \\
\text { which learners can comment on the effectiveness of various } \\
\text { reading strategies. }\end{array}$ \\
\hline 5 & Expansion & $\begin{array}{l}\text { Students try to expand and transfer their learned strategies } \\
\text { to other similar contexts and reading tasks. They may also } \\
\text { create their own personal combinations of reading } \\
\text { strategies. Up to this stage, the objective of strategy-based } \\
\text { instruction has been accomplished, the learners have } \\
\text { gained adequate competence to use strategies } \\
\text { independently and have the self-regulated capacity to take } \\
\text { the responsibility of their own learning. }\end{array}$ & $\begin{array}{l}\text { Students use the previously taught strategies or their own } \\
\text { individual mixtures of reading strategies while reading short } \\
\text { stories outside the class. }\end{array}$ \\
\hline
\end{tabular}

In the meantime, the control group students were taught traditionally without receiving any explicit instruction of L2 reading strategies. More specifically, the procedure 
adopted for the control group was to make the students read a text aloud and translate it. During the sessions, the teacher taught the new vocabularies and provided the students with oral comprehension questions following passage reading.

To measure the participants' performance on reading comprehension, two different versions of the reading component of CPET were administered as pre-test (i.e., prior to reading strategy instruction) and post-test (after the reading strategy instruction) of the study.

\section{FINDINGS}

In order to statistically analyze the data, the Statistical Package for Social Sciences (SPSS) version 20.0 was employed. As pointed out above, OPT was administered to guarantee the homogeneity of the students of the experimental and control groups with regards to general language proficiency before starting the reading strategy-based instruction. For the analysis of the OPT scores, an independent-samples t-test was carried out to compare the OPT scores for the students of experimental and control groups. As presented in Table 2, the results indicated that there was not a statistically significant difference in the OPT scores for the experimental group $(M=35.72, S D=$ $10.05)$ and the control group $(M=36.11, S D=9.84) ; t(46)=-.642, p>0.05)$, revealing that the two groups were not statistically different in terms of general English proficiency prior to conduction of the treatment.

Table 2

Results of the OPT for Each Group

\begin{tabular}{llll}
\hline Groups & M (SD) & $t$ & Sig. \\
\hline Experimental & $35.72(10.05)$ & -.642 & .412 \\
Control & $36.11(9.84)$ & & \\
\hline
\end{tabular}

Afterwards, in order to explore the effect of the reading strategy-based instruction program on the participants' reading comprehension, first paired samples $t$-tests were conducted to compare the reading comprehension scores of the learners in both experimental and control groups on the pre-test and post-test. The results of paired samples t-tests demonstrated that there was a statistically significant increase of mean scores on the reading comprehension tests for the students of both experimental and control groups. As the results in Table 3 indicate, the increase in the reading mean scores of the experimental group was statistically significant $(\mathrm{t}(24)=-29.33, \mathrm{p}<0.05)$, likewise, the increase in the reading comprehension mean scores of the control group was statistically significant $(\mathrm{t}(22)=-7.88, \mathrm{p}<0.05)$. The results also revealed that the reading mean score of the experimental group was $17.84(\mathrm{SD}=4.32)$ on the pre-test and this value increased to $25.20(\mathrm{SD}=4.66)$ on the post-test, an increase which was statistically significant. Likewise, the reading comprehension pre-test mean score for the control group increased from $16.95(\mathrm{SD}=4.65)$ to $20.78(\mathrm{SD}=5.34)$ on the post-test, an increase which was also statistically significant. 
Table 3

Paired Samples T-test for Reading Scores in Each Group

\begin{tabular}{|c|c|c|c|c|c|c|}
\hline \multirow[b]{2}{*}{ Groups } & \multicolumn{2}{|c|}{ Pre-test } & \multicolumn{2}{|c|}{ Post-test } & \multirow[b]{2}{*}{$\mathrm{t}$} & \multirow[b]{2}{*}{ Sig. } \\
\hline & $\mathrm{M}$ & SD & $M$ & SD & & \\
\hline Experimental & 17.84 & 4.32 & 25.20 & 4.66 & -29.33 & 0.00 \\
\hline Control & 16.95 & 4.65 & 20.78 & 5.34 & -7.88 & 0.00 \\
\hline
\end{tabular}

Moreover, a one-way between-groups analysis of covariance (ANCOVA) was carried out to compare the effectiveness of the two types of second language reading instructions used in the control group and the experimental groups. The independent variable was the type of treatment condition (i.e. strategy-based instruction or traditional), and the dependent variable was the scores on the reading comprehension test administered after the completion of the intervention. Participants' scores on the pre-test of the reading comprehension test acted as the covariate in the ANCOVA analysis.

Table 4

ANCOVA Results for Reading Comprehension Scores

\begin{tabular}{|c|c|c|c|c|c|c|}
\hline Source & $\begin{array}{l}\text { Type III } \\
\text { Squares }\end{array}$ & $\mathrm{df}$ & Mean Square & $\mathrm{F}$ & Sig. & $\begin{array}{l}\text { Partial Eta } \\
\text { Squared }\end{array}$ \\
\hline Corrected Model & $1227.797^{\mathrm{a}}$ & 2 & 613.898 & 177.234 & .000 & .887 \\
\hline Intercept & 71.001 & 1 & 71.001 & 20.498 & .000 & .313 \\
\hline Pre.Reading & 994.043 & 1 & 994.043 & 286.983 & .000 & .864 \\
\hline Group & 145.460 & 1 & 145.460 & 41.995 & .000 & .483 \\
\hline Error & 155.870 & 45 & 3.464 & & & \\
\hline Total & 26960.000 & 48 & & & & \\
\hline Corrected Total & 1383.667 & 47 & & & & \\
\hline
\end{tabular}

Preliminary checks demonstrated that the assumptions of normality, linearity, homogeneity of variances, homogeneity of regression slopes, and reliable measurement of the covariate were not violated. As Table 4 shows, there was a significant difference between the two groups on post-test scores of reading comprehension, $F(1,45)=41.99$, $p=0.000$, partial eta squared $=0.48$ ). The results of ANCOVA indicated that the students of the experimental group outperformed those of control group on the post-test of reading comprehension.

\section{DISCUSSION AND CONCLUSION}

The current study was conducted to investigate the effectiveness of implementing a reading strategy instruction program in improving young Iranian EFL learners' reading comprehension. The CALLA strategy instruction model was adopted for the experimental intervention lasting for twelve weeks. The results of this research indicated that the students of the experimental group significantly outperformed those of control group with regard to reading comprehension ability, suggesting that the reading strategy instruction was influential in fostering L2 reading comprehension of the young Iranian EFL learners. The results of this research are in agreement with those of previous empirical studies (Aghaie \& Zhang, 2012; Akkakoson, 2013; Dabarera, Renandya, \& Zhang, 2014; Zhang, 2008, among others) and are at variance with the findings of Shang 
(2010). More particularly, concerning the young EFL learners as the participants of this study, it was revealed that the findings of the present study corroborated and extended the findings of Manoli, Papadopoulou, and Metallidou (2016) that supported the effectiveness of strategy use and instruction in improving reading comprehension among young, school-aged students. Also, the findings of this study are partially in line with those of Shih and Reynolds (2018) who found that reading strategy instruction significantly contributed to improving reading proficiency and motivation of the L2 learners. However, the findings of the present study did not confirm those of Mehrpour, Sadighi, and Bagheri (2012) who found that strategy-based reading instruction did not enhance the participants' reading comprehension of Iranian EFL pre-university students.

The enhanced performance of young EFL learners after receiving strategy-based instruction may support the claim that younger students are more likely to acquire language learning strategies than the older language learners (Dobson, 1998). As a result, strategy instruction at early ages can boost EFL learners' confidence and competence in employing effective language strategies in their own classes thereby improving their language proficiency (Manoli, Papadopoulou, \& Metallidou, 2016).

Additionally, the findings of the present verify the effectiveness of L2 reading strategy instruction in improving reading comprehension of L2 learners who became more goaloriented in text-information processing (Erler \& Finkbeiner, 2007; Grabe, 2009). The improved reading performance of the participants of experimental group also supports the findings of Yang (2006), suggesting that L2 learners can employ reading strategies to compensate for their reading shortcomings and inadequate language knowledge in understanding a text. As L2 reading involves both a language and a reading problem (Koda, 2007), explicit instruction of reading strategies can help L2 readers to acquire effective reading habits by which they can improve their comprehension abilities. Such effective reading habits are not naturally acquired through implicit learning. Hence, L2 readers should be instructed on how to use these reading strategies in their own reading process. In fact, L2 learners should be equipped with a repertoire of reading strategies through instructional programs in which students learn how to properly use strategies by receiving explicit reading strategy instruction involving strategy explanation, modeling, and practice.

Also, it may be argued that reading strategy instruction employed in this study contributed to raising the participants' metacognitive awareness of L2 reading strategies and enhancing their employment of reading strategies during the conduction of reading tasks. The effectiveness of reading strategy instruction in enhancing metacognitive awareness of reading strategies and increased strategy use has been reported by a significant number of previous studies (e.g., Akkakoson, 2013; Macaro \& Erler, 2008; Ruiz de Zarobe \& Zenotz, 2018; Salataci \& Akyel, 2002; Teng, 2019).

As far as practical implications of the study are concerned, it is suggested that EFL practitioners need to integrate reading strategy instruction into their regular L2 classrooms in order to improve reading performance of their students (Ghaith, 2018). Nevertheless, the teachers themselves should be trained on how to teach strategies 
effectively. If teachers are now equipped with the knowledge and awareness of reading strategies, they will not be able to implement strategy-based instruction (Zhang \& Wu, 2009). Strategy-based instruction, however, may increase the burden and responsibilities of EFL teachers in the so-called postmethod era in which the language teachers are claimed to be inadequately supported by teacher education programs (Fathi, \& Behzadpour, 2011; Khatib \& Fathi, 2015). As a result, teacher education programs should adopt the necessary imperatives to prepare pre-service EFL teachers to apply reading strategies in their own classroom. More particularly, serious attention should be paid to strategy instruction by language policy makers and curriculum planners in Iran where strategy instruction has been neglected and not been incorporated into EFL instruction systematically. Given the particular findings of the present study, reading strategy instruction can be initiated from the early L2 instruction for the young L2 learners in Iran.

As one noticeable limitation of the present study, it is worth noting that the present study failed to employ qualitative data collection procedure to assess the participants' metacognitive awareness and reading strategy use before and after the reading strategybased instruction program. Further studies should employ bigger samples with various language proficiency levels to increase the generalizability of the findings. Moreover, longitudinal designs can be used so as to uncover long-term gains of strategy instruction programs.

\section{REFERENCES}

Abbott, M. L. (2006). ESL reading strategies: Differences in Arabic and Mandarin speaker test performance. Language Learning, 56(4), 633-670.

Aghaie, R., \& Zhang, L. J. (2012). Effects of explicit instruction in cognitive and metacognitive reading strategies on Iranian EFL students' reading performance and strategy transfer. Instructional Science, 40(6), 1063-1081.

Akkakoson, S. (2013). The relationship between strategic reading instruction, student learning of mL2-based reading strategies and L2 reading achievement. Journal of Research in Reading, 36(4), 422-450.

Allan, D. (2004). Oxford placement test. Oxford: Oxford University Press.

Anderson, N. J. (1991). Individual differences in strategy use in second language reading and testing. Modern Language Journal, 75(4), 460-472.

Ary, D., Jacobs, L. C., Irvine, C. K. S., \& Walker, D. (2018). Introduction to research in education. Cengage Learning.

Bimmel, P. E., van den Bergh, H., \& Oostdam, R. J. (2001). Effects of strategy training on reading comprehension in first and foreign language. European Journal of Psychology of Education, 16(4), 509-529.

Bouvet, E., \& Close, E. (2011). Online reading strategy guidance in a foreign language: Five case studies in French. Australian Review of Applied Linguistics, 29(1), 7.1 - 7.13 
Brown, A., \& Palincsar, A. (1989). Guided cooperative learning and individual acquisition. In L. B. Resnil (Ed.). Knowing, learning, and instruction: Essays in honor of Robert Glaser (pp. 393-451). Hillsdale, NJ: Erlbaum.

Carrell, P. L., Pharis, B. G., \& Liberto, J. G. (1989). Metacognitive strategy training for ESL reading. TESOL Quarterly, 20, 463-494.

Chamot, A. U. (2005). Language learning strategy instruction: current issues and research. Annual Review of Applied Linguistics, 25, 112-130.

Chamot, A. U., Barnhardt, S., El-Dinary, P. D., \& Robbins, J. (1999). The Learning strategies handbook. New York: Pearson Education.

Chamot, A. U., \& O'Malley, J.M. (1994). The CALLA handbook: Implementing cognitive academic language learning approach. New York: Addison-Wesley.

Chamot, A. U., \& O'Malley, J. M. (1996). Implementing the cognitive academic language learning approach (CALLA). In R. B. Oxford (Ed.), Language learning strategies around the world: Cross-cultural perspectives (pp. 167-174). Manoa, Hawaii: University of Hawaii Press.

Cohen, A. D. (2007). Strategies in learning and using a second language. London and New York: Longman.

Cohen, A. D., \& Weaver, S. J. (2005). Styles and strategies-based instruction: A teachers' guide. CARLA Working Paper Series A rewritten version of Paper 7. University of Minnesota. Retrieved from http://elechina.super-red.es/cohen-weaver.pdf.

Çubukçu, F. (2008). How to enhance reading comprehension through metacognitive strategies. The Journal of International Social Research, 2, 83-93.

Dabarera, C., Renandya, W. A., \& Zhang, L. J. (2014). The impact of metacognitive scaffolding and monitoring on reading comprehension. System, 42, 462-473.

Davis, D. S. (2010). A meta-analysis of comprehension strategy instruction for upper elementary and middle school students (Unpublished doctoral dissertation). Vanderbilt University, US.

Dobson, A. (1998). MFL Inspected: Reflections on inspection findings 1996/97. London: CILT.

Duke, N., \& Pearson, P. D. (2002). Effective practices for developing reading comprehension. In A. E. Farstrup, \& S. J. Samuels (Eds.), What research has to say about reading instruction (pp.205-242). Newark, DE: International Reading association.

Erler, L., \& Finkbeiner, C. (2007). A review of reading strategies: focus on the impact of first language. In A. D. Cohen, \& E. Macaro (Eds.), Language learner strategies (pp. 187-206). Oxford: Oxford University Press.

Fathi, J., \& Behzadpour, F. (2011). Beyond method: The rise of reflective teaching. International Journal of English Linguistics, 1(2), 241-252. 
Fathi, J., \& Hamidizadeh, R. (2019). The contribution of listening strategy instruction to improving second language listening comprehension: A case of Iranian EFL learners. International Journal of Instruction, 12(2), 17-32.

Ghaith, G. M. (2018). English as a second/foreign language reading comprehension: A framework for curriculum and instruction. TESL Reporter, 50(2), 1-17.

Grabe, W. (2009). Reading in a second language: Moving from theory to practice. New York: Cambridge University Press.

Kern, R. G. (1989). Second language reading strategy instruction: Its effects on comprehension and word inference ability. The Modern Language J., 73, 135-149.

Khatib, M., \& Fathi, J. (2015). The investigation of the perspectives of Iranian EFL domain experts on post-method pedagogy: A Delphi technique. Journal of Teaching Language Skills, 33(3), 89-112.

Koda, K. (2007). Reading and language learning: Cross-linguistic constraints on second language reading development. Language Learning, 57(1), 1-44.

Liao, H. C., \& Wang, Y. H. (2018). Using comprehension strategies for students' selfefficacy, anxiety, and proficiency in reading English as a foreign language. Social Behavior and Personality, 46(3), 447-458

Macaro, E., \& Erler, L. (2008). Raising the achievement of young-beginner readers of French through strategy instruction. Applied Linguistics, 29(1), 90-119.

Manoli, P., Papadopoulou, M., \& Metallidou, P. (2016). Investigating the immediate and delayed effects of multiple-reading strategy instruction in primary EFL classrooms. System, 56, 54-65.

Mehrpour, S., Sadighi, F., \& Bagheri, Z. (2012). Teaching reading comprehension strategies to Iranian EFL pre-university students. Journal of Teaching Language Skills (JTLS), 4(1), 107-139.

Naseri, M., \& Zaferanieh, E. (2012). The relationship between reading self-efficacy beliefs, reading strategy use and reading comprehension level of Iranian EFL learners. World Journal of Education, 2, 64-75.

O’Malley, J., \& Chamot, A. (1990). Learning strategies in second language acquisition. Cambridge, UK: Cambridge University Press.

Oxford, R., Cho, Y., Leung, S., \& Kim, H. (2004). Effect of the presence and difficulty of task on strategy use: An exploratory study. IRAL (International Review of Applied Linguistics in Language Teaching), 42, 1-47. https://doi.org/10.1515/iral.2004.001.

Oxford, R. L. (2011). Teaching and researching language learning strategies. London: Pearson/Longman.

Phakiti, A. (2003). A closer look at the relationship of cognitive and metacognitive strategy use to EFL reading achievement test performance. Language Testing, 20(1), 2656 . 
Plonsky, L. (2011). The effectiveness of second language strategy instruction: a metaanalysis. Language Learning, 61(4), 993-1038.

Ruiz de Zarobe, Y., \& Zenotz, V. (2018). Learning strategies in CLIL classrooms: how does strategy instruction affect reading competence over time? International Journal of Bilingual Education and Bilingualism, 21(3), 319-331.

Salataci, R., \& Akyel, A. (2002). Possible effects of strategy instruction on L1 and L2 reading. Reading in a foreign language, 14(1), 234-255.

Shang, H. F. (2010). Reading strategy use, self-efficacy and EFL reading comprehension. Asian EFL Journal, 12 (2), 18-42.

Sheorey, R., \& Mokhtari, K. (2001). Differences in the metacognitive awareness of reading strategies among native and non-native readers. System, 29(4),431-449.

Shih, Y. C., \& Reynolds, B. L. (2018). The effects of integrating goal setting and reading strategy instruction on English reading proficiency and learning motivation: A quasi-experimental study. Applied Linguistics Review, 9(1), 35-62.

Takallou, F. (2011). The effect of metacognitive strategy instruction on EFL learners' reading comprehension performance and metacognitive awareness. Asian EFL Journal, 12(1), 272-300.

Taylor, A., Stevens, J., \& Asher, J. W. (2006). The effects of explicit reading strategy training on L2 reading comprehension. In J. M. Norris \& L. Ortega (Eds.), Synthesizing research on language learning and teaching (pp. 213-244). Philadelphia, PA: John Benjamins.

Teng, F. (2019). The benefits of metacognitive reading strategy awareness instruction for young learners of English as a second language. Literacy.

Williams, M., \& Burden, R. (1997). Psychology for language teachers. Cambridge: Cambridge University Press.

Wright, M. \& Brown, P. (2006). Reading in a modern foreign language: exploring the potential benefits of reading strategy instruction. Language Learning J., 33, 22-33.

Yang, Y. (2006). Reading strategies or comprehension monitoring strategies? Reading Psychology, 27, 313-343.

Zhang, L. J. (2008). Constructivist pedagogy in strategic reading instruction: exploring pathways to learner development in the English as a second language (ESL) classroom. Instructional Science, 36(2), 89-116.

Zhang, L. J., \& Wu, A. (2009). Chinese senior high school EFL students' metacognitive awareness and reading-strategy use. Reading in a Foreign Language, 21(1), 37-59.

Ziegler, J. C., \& Goswami, U. (2006). Becoming literate in different languages: Similar problems, different solutions. Developmental Science, 9(5), 429-436. 